\title{
Studi Kritis Terhadap Pandangan Muhammad Al-Ghazali Tentang Hadis Âhâd dalam Kitab As-Sunnah Al-Nabawiyyah Baina Ahl Al-Fiqh Wa Ahl al-Hadits
}

(A Critical Study of Muhammad Al-Ghazali's View of the Âhat Hadith in the Book of As-Sunnah Al-Nabawiyyah Baina Ahl Al-Fiqh Wa Ahl al-Hadits)

\author{
Ardiansyah, Heri Firmansyah \\ UIN Sumatera Utara Medan, Indonesia \\ ardiansyah@uinsu.ac.id, herifirmansyah@uinsu.ac.id
}

DOI: $10.29240 /$ alquds.v5i2.2792

Submitted: 2021-05-16| Revised: 2021-09-07| Accepted: 2021-09-13

\begin{abstract}
One of the leading contemporary muhaddist scholars who came from Egypt is Sheikh Muhammad Al-Ghazali. Among his monumental works in the study of hadith is a book of hadith criticism entitled "as-Sunnah al-Nabawiyyah baina Ahl al-Fiqh wa Ahl al-Hadîts". This article seeks to explain how Sheikh al-Ghazali's views in providing a method for understanding authentic hadiths and the position of ahad hadith as the basis of Islamic law as well as some of his criticisms of the weaknesses of the observations of some ahad hadith even though in some assessments of classical scholars it falls into the category of sahih hadith. The method used in this paper is content analysis, which examines the thoughts of Sheikh Muhammad al-Ghazali on the book he wrote regarding the hadith of ahad, with an empirical rationality approach The ahad hadith that are used as examples in Shaykh al-Ghazali's criticism in this paper are the hadith about flies and the hadith about the prohibition of songs and music. For Sheikh Al-Ghazali, it is not a problem for someone not to practice the hadith Ahad, even if it is authentic (shahib), as long as the hadith is not about faith and the pillars of Islam, such as not practicing the hadith about flies and musics, because this will not damage and disturb one's faith and Islam.
\end{abstract}

Keyword: Critic of Matan; Ahad Hadith; Muhammad Al-Ghazali

\begin{abstract}
Abstrak. Salah satu ulama muhaddis kontemporer terkemuka yang berasal dari Mesir adalah Syeikh Muhammad Al-Ghazali. Diantara karya monumentalnya dalam kajian hadis adalah buku kritik hadis berjudul "as-Sunnah al-Nabawiyyah baina Ahl al-Fiqh wa Ahl alHadits". Artikel ini berusaha untuk menjelaskan bagaimana pandangan Syeikh al-Ghazali dalam memberikan metode terhadap pemahaman hadis shahih dan kedudukan hadis ahad sebagai landasan hukum Islam serta beberapa kritikan yang dilakukannya terhadap kelemahan matan beberapa hadis ahad meskipun dalam beberapa penilaian ulama klasik masuk dalam kategori hadis shahih. Metode yang digunakan dalam penulisan ini adalah
\end{abstract}


analisis konten, yakni mengkaji pemikiran Syeikh Muhammad al-Ghazali terhadap buku yang ditulisnya yang berkenaan dengan hadis ahad, dengan pendekatan rasionalitas empiris. Hadis ahad yang dijadikan contoh dalam kritikan Syeikh al-Ghazali dalam tulisan ini adalah hadis tentang lalat dan hadis tentang pengharaman lagu dan musik. Bagi Syeikh Al-Ghazali, tidak menjadi masalah bagi seseorang untuk tidak mengamalkan hadis ahad, meskipun berderajat shahih, selama hadis tersebut bukanlah berkenaan tentang keimanan dan rukun Islam, seperti misalnya tidak mengamalkan hadis tentang lalat dan musik, karena hal ini tidak akan merusak dan mengganggu keimanan dan keislaman seseorang.

Kata Kunci : Kritik Matan; Hadis Ahad; Muhammad al-Ghazali.

\section{Pendahuluan}

Syeikh Muhammad al-Ghazâlî adalah sosok ulama kharismatik dan terkemuka berasal dari Mesir. Dalam perjalanan karir keilmuannya, ia telah menghasilkan buku-buku dan artikel dalam berbagai bidang kajian keislaman. Diantara karya monumentalnya dalam kajian hadis adalah buku kritik hadis berjudul "as-Sunnah al-Nabawiyyah baina Abl al-Fiqh wa Abl al-Hadîts". Kitab ini banyak mendapatkan tanggapan dan komentar baik yang pro dan kontra dari berbagai kalangan khususnya dari ulama hadis. ${ }^{1}$ Bahkan ada yang mengkafirkan dan menuduhnya terpengaruh dengan doktrin orientalis dan paham Muktazilah. ${ }^{2}$ Serangan, kritikan dan celaan terhadap M. al-Ghazâlî disebabkan; pertama ia tidak menjadikan hadis Âhâd sebagai hujjah dalam permasalahan aqidah. Kedua, penolakannya terhadap beberapa hadis shahih yang berstatus Âhâd serta kritikan kerasnya terhadap ulama hadis sehingga ia dituduh menolak hadis. Ketiga, penggunaan hadis-hadis dhaif dalam beberapa buah bukunya. Namun demikian, pandangan al-Ghazâlî ini bukanlah pendapat baru. Sebelumnya telah ditemukan pendapat sama dari ulama besar seperti Imam al-Juwayni, Abu Hâmid al-Ghazali, al-Bazdawi, al-Isnawi, al-Nawawi, al-Khatîb al-Baghdâdi, al-Baqilâni dan al-'Irâqi. Oleh karena itu, penolakan sebagian ulama terhadap kritik hadis yang dilakukan oleh syeikh M. al-Ghazâlî ini menjadi menarik untuk diteliti.

Beberapa tulisan mengenai pandangan Syeikh Muhammad al-Ghazali tentang hadis ahad adalah seperti tulisan Syahidin "Kehujahan Hadis Ahad menurut

${ }^{1}$ Diantara kitab yang mengkritik pemikiran M. al-Ghazâlî adalah kitab al-Hiwâr al-Hâdi' ma'a Mubammad al-Ghazâlî karya Syeikh Dr. Salman bin Fahd al-'Audah diterbitkan oleh Dâr aWathan di Riyadh tahun 1992. Kitab ini merupakan komentar sekaligus kritikan terhadap metode yang dipergunakan Syeikh al-Ghazâlî dalam meneliti kualitas hadis khsusnya yang berkaotan dengan hadis-hadis Âhâd.

${ }^{2}$ Rabî’ bin Hâdi al-Madhkalî, Kasyf Mawqif al-Ghazâlî min al-Sunnah wa Ablihâ, (al-Madinah al-Munawwarah: Maktabah Ibnu al-Qayyim, 1991), h. 196. Bandingkan dengan syeikh al-Albânî, Shifat Shalât al-Nabi, (Riyadh, Maktabat al-Ma'ârif, 2002), h. 68. Namun demikian, komentar yang menyudutkan syeikh M. al-Ghazâlî dalam kitab syeikh Rabi’ tersebut telah dibantah pula oleh Dr. Ahmad Hijâzî al-Saqqâ dalam Daf'u al-Syububât 'an Syeikh Mubammad al-Ghazali, dicetak di Kairo oleh Maktabah al-Kulliyyât al-Azhariyyah pada tahun 1990. 
Muhammad al-Ghazali, suatu kajian terhadap otoritas hadis ahad sebagai sumber ajaran Islam. ${ }^{3}$ Tulisan ini membahas tentang kehujahan hadis ahad sebagai salah satu sumber ajaran Islam, memberikan kesimpulan bahwa pandangan Muhammad alGhazali dalam persoalan furuiyyah hadis ahad dapat digunakan sebagai landasan hukum, sedangkan dalam akidah tidak dapat digunakan.

Tulisan yang memberikan perhatian terhadap pandangan Muhammad AlGhazali dan pandangannya tentang hadis lainnya adalah tulisan Abdul Basid berjudul "Kritik Terhadap Metode Muhammad Al-Ghazali Dalam Memahami Hadits Nabi Muhammad Saw". ${ }^{4}$ Tulisan ini menitik beratkan pada kritik terhadap pandangan Muhammad al-Ghazali dalam memahami hadis terutama hadis ahad sebagai landasan akidah dan hukum Islam.

Kemudian tulisan Sri Purwaningsih dengan judul "Kritik Terhadap Rekonstruksi Metode Pemahaman Hadis muhammad Al-Ghazali" ${ }^{5}$ Dalam tulisannya, Sri Purwaningsih menitik beratkan pada dua pembahasan, yakni mengkritik aplikasi metode pemahaman hadis Muhammad al-Ghazali, dan menawarkan bentuk rekonstruksi metode yang baru dengan menggunakan metode analisis deskriptif dan berikut penjelasannya. Kedua tulisan di atas berusaha untuk memberikan kritikan terhadap pandangan al-Ghazali terhadap konsep memahami hadis, seperti juga yang disampaikan oleh beberapa ulama kontemporer.

Tulisan lainnya yang memiliki keterkaitan dengan kajian yang dibahas ini adalah tulisan Mhd. Idris dengan judul "Metode Pemahaman Hadis Muhammad Al-Ghazali". ${ }^{6}$ Dalam kesimpulannya penulis menyatakan bahwa Muhammad alGhazali menawarkan empat kriteria dalam memahami matan hadis yaitu: matan hadis harus sesuai dengan al-Qur`an, matan hadis harus sesuai hadis shahih lainnya, matan hadis harus sesuai dengan fakta sejarah, matan hadis harus sesuai dengan kebenaran ilmiah. Dalam kajiannya ini Mhd Idris tidak menyinggung tentang persoalan hadis Ahad seperti yang ada dalam kajian dalam tulisan ini.

Keempat tulisan di atas meskipun memiliki ketersinggungan dan keterkaitan dengan kajian yang sedang dibahas namun jika ditinjau lebih

${ }^{3}$ Syahidin Syahidin, "Kehujahan Hadis Ahad menurut Muhammad al-Ghazali, suatu kajian terhadap otoritas hadis ahad sebagai sumber ajaran Islam", Jurnal El-Afkar Vol. 6 Nomor 1, Januari-Juni 2017.

${ }^{4}$ Abdul Basid, "Kritik Terhadap Metode Muhammad Al-Ghazali Dalam Memahami Hadits Nabi Muhammad Saw", Jurnal Kabilab Vol. 2 No. 1 Juni 2017, h. 1-35.

5 Sri Purwaningsih, "Kritik Terhadap Rekonstruksi Metode Pemahaman Hadis muhammad Al-Ghazali", Jumal THEOLOGIA, Vol 28 No 1 (2017), h. 75-102.

${ }^{6}$ Mhd. Idris, "Metode Pemahaman Hadis Muhammad Al-Ghazali" Jurnal Ulunnuha Vol.6 No.1/Juni 2016, h. 27-36. 
mendalam tidak ada yang memiliki kemiripan dari sisi fokus pembahasannya, seperti contohnya hadis ahad yang menjadi pusat kritikan Muhammad al-Ghazali dan mengapa Syeikh al-Ghazali memberikan kritik matan terhadap hadis ahad tersebut meskipun ulama klasik menilai hadis tersebut dalam kategori shahih karena salah satunya termuat dalam kitah shahih al-Bukhari. Karena itu tulisan ini dapat menjadi sebuah khazanah baru dalam diskursus pembahasan mengenai kedudukan dan kritik hadis Ahad dalam perspektif Syeikh Muhammad AlGhazali.

Pembahasan tentang pemikiran Syeikh Muhammad Al-Ghazali mengenai kritik matan hadis ahad dengan pendekatan rasionalitas empiris sangat penting karena mayoritas hadis-hadis Rasulullah saw dalam segi periwayatannya bersatus hadis $a h a>d$ sebagai lawan hadis mutawatir yang keberadaannya tidak lebih dari 1\% dari keseluruhan hadis Rasulullah saw. Dengan demikian, kritikan terhadap hadis ahad, berarti memberikan kritikan dan koreksi terhadap mayoritas hadishadis Rasulullah saw, dengan pendekatan rasionalitas empiris, yang berarti sesuai dengan pola pemikiran yang realitis dan perkembagan kehidupan masyarakat modern saat ini. Metode yang digunakan dalam tulisan ini adalah content analysis, yakni mengkaji pemikiran Syaikh Muhammad al-Ghazali tentang hadis ahad dalam bukunya Al-Sunnah al-Nabawiyah baina Abl al-Fiqh wa Abl al-Hadits.

\section{Biograpi Syeikh M. al-Ghazali}

Syeikh M. Al-Ghazâlî dilahirkan pada 22 September 1917, di kampung Naklal Inab, Buhairah - Mesir. Beliau dibesarkan dalam lingkungan keluarga pedagang yang taat beragama. Ayahnya adalah seorang hâfiz̧ al-Qur'ân, sehingga hal itu sangat mempengaruhi semangat M. al-Ghazâlî untuk mengikuti jejak ayahandanya. Sejak usia dini ia telah memulai menghafal al-Qur'ân dan berhasil menghafalnya pada usia sepuluh tahun. Hal ini sekaligus menunjukkan kecerdasan M. al-Ghazâlî muda ini yang kelak akan tumbuh menjadi sosok ulama yang kharismatik dan juga kritis.

Syeikh Muhammad Al-Ghazâlî menimba ilmu dari para ulama di kampungnya sampai ia menamatkan pendidikan tsanawiyah (setingkat SMU). Kemudian ia pindah ke Kairo untuk melanjutkan kuliah di Fakultas Ushuluddin Universitas al-Azhar dan lulus tahun 1941 M. Sikap teliti dan kritis terhadap berbagai permasalahan sudah terlihat sejak ia duduk dibangku perkuliahan. Dalam waktu satu tahun ia menyelesaikan program magister dalam bidang Dakwah wa al-Irsyâd dan mendapat gelaran Magister pada tahun 1943 M. Diantara guru yang banyak memberikan kontribusi dalam pembentukan pemikirannya ialah syeikh Mahmud Syaltut, syeikh Abdul Aziz Bilal, syeikh Ibrahim Al-Gharbawi, dan syeikh Abdul Azhîm Az-Zarqani.

Pada tahun 1943 M. al-Ghazâlî bertemu dengan pemimpin Ikhwanul Muslimin yaitu Hasan al-Banna (w. 1368 H/ 1949M) dan bergabung dalam 
barisannya. Sikap kritisnya terhadap berbagai persoalan umat dan keprihatinannya terhadap kemerosotan moral anak muda menjadi pusat perhatiannya. Berbagai kegiatan dan jabatan telah ia lalui sebagai sarana untuk menyampaikan dakwah di tengah-tengah umat dan penyuluhan Islam bagi masyarakat awam. Berbagai keberhasilan ia capai sehingga pada 02 Juli 1981 M syeikh M. al-Ghazâlî diangkat menjadi wakil kementerian Wakaf dan Dakwah Islam. Ia juga mantan dosen di berbagai universitas terkemuka di Timur-tengah seperti universitas Umm al-Qurâ di Mekkah al-Mukarramah, Universitas al-Amir Abd al-Qadir di al-Jazair, dan Fakultas Syari'ah di Qatar.

Syeikh Muhammad al-Ghazâlî wafat di Riyadh, Arab Saudi pada tanggal 9 Maret 1996 M. Jenazahnya dipindahkan ke kota Madinah al-Munawwarah, untuk dimakamkan di pemakaman al-Baqi'. Gubernur kota Madinah yang mulia Amir Abdullah bin Abd al-'Aziz Âl Su'ûd memiliki peranan penting ketika memberikan penghargaan kepada Syeikh M. al-Ghazali, baik ketika masih hidup maupun setelah beliau meninggal serta memberikan bantuan kepada keluarganya. Syeikh M. al-Ghazâlî meninggalkan sembilan orang anak buah pernikahannya ketika masih kuliah di Fakultas Ushuluddin. ${ }^{8}$

Syeikh Muhammad al-Ghazâlî termasuk ulama yang produktif menulis. Sekitar enam puluh buku telah beliau hasilkan yang berasal dari berbagai kajian dan berbagai sumber seperti dari ceramah, makalah seminar, buletin, khutbah, nasehat, dan dialog yang beliau sampaikan di Mesir maupun di tempat-tempat yang lain. Sebagian besar buku-buku tersebut telah diterjemahkan ke berbagai bahasa antara lain bahasa Inggris, Turki, Prancis, Urdu, dan Indonesia.'

Dr. Yusuf Al-Qaradhawi pernah berkomentar tentang M. al-Ghazâlî seraya berkata: "Mungkin anda berbeda pandangan dengan al-Ghazali, atau beliau berbeda pendapat dengan anda dalam masalah-masalah kecil ataupun besar, sedikit atau banyak masalah. Akan tetapi jika anda mengenalinya dengan baik, anda pasti akan mencintai dan menghormatinya. Karena anda akan mengetahui keikhlasan dan ketundukannya kepada kebenaran, istiqomah dalam pendapat, dan ghirahnya yang murni untuk Islam. Memang Syeikh al-Ghazâlî adalah seorang yang mudah tersinggung. Kemarahannya meluap-luap seperti ombak lautan yang menghantam pantai atau seperti letusan gunung berapi yang dahsyat. Beliau mempunyai sikap seperti itu karena ia sangat membenci kezaliman dan penghinaan, baik pada dirinya atau orang lain, tidak suka berlaku zalim atau dizalimi. Beliau seorang yang tidak suka merendahkan kehormatan orang lain

${ }^{7}$ Mahmud Jami', Ikhwanul Muslimin yang Saya Kenal, terj. Munirul Abidin, (Jakarta: Pustaka al-Kautsar, 2005), h. 177.

${ }^{8}$ Ibid.

${ }^{9}$ Ibid., h. 180. 
sebagaimana ia juga tidak suka direndahkan oleh siapapun. Ia juga sangat membenci pemikiran yang menyimpang khususnya berkaitan dengan agama dan akan memerangi itu semua secara terang-terangan. Meskipun ia seorang yang mudah marah, namun kemarahannya tersebut segera mereda dan tidak memiliki sifat dendam sedikitpun. Kebenaran adalah tolak ukurnya, sehingga ketika ia menemukan pendapat yang lebih benar dan mendapatkan penjelasannya, maka ia akan segera berpihak kepada kebenaran tersebut. Inilah keberanian yang tidak dimiliki kecuali oleh sebagian kecil manusia... Syeikh Muhammad al-Ghazâlî mengakui kemuliaan dan keutamaan ulama lain seperti Syeikh Sayyid Sâbiq, Syeikh Abdul Muiz Abd al-Sattâr, Syeikh Zakaria Az-Zaukah, dan Syeikh Ismail Hamdi. Saya sangat malu ketika beliau berkata di depan umum: "Bertanyalah kepada Yusuf Al-Qaradhawi, karena ia lebih utama dariku. Dulu ia muridku, tapi sekarang aku muridnya!" Sikap seperti ini tidak dimiliki kecuali oleh orang-orang yang benar-benar tulus ikhlas". ${ }^{10}$

Selain itu, Syeikh Al-Azhar, Dr. Abdul Halîm Hamîd Mahmûd, mengakui kemuliaan dan membanggakan Syeikh M. al-Ghazâlî dengan mengatakan: "Kita punya al-Ghazâlî yang masih hidup dan al-Ghazâlî penyusun kitab Al-Ihya'." Aktivis muda Islam memperoleh manfaat dari ilmu, keberanian, keterus-terangan, kejujuran, dan kejelasan sikap Syeikh Muhammad al-Ghazali. Ia mempunyai kader di al-Azhar Mesir, Umm al-Qurâ di Makkah Al-Mukarramah, Fakultas Syari’ah Qatar, Universitas al-Amir Abdul Qadir li al-'Ulûm al-Islâmiyah Aljazair, dan kader lain yang terbina melalui khutbah, kajian, ceramah, seminar, buku, makalah, pertemuan, dan muktamar. ${ }^{11}$

\section{Hadis Âhâd menurut Muhammad al-Ghazali}

Pandangan M. al-Ghazâlî tentang hadis Âhâd menimbulkan kontroversi terutama di kalangan ulama hadis. Menurut syeikh al-Ghazâlî hadis Âhâd berstatus ₹hanni al-tsubût (diragukan statusnya). Menurutnya, perkara aqidah tidak dapat diambil melainkan dari nash yang pasti dari segi tsubût (status) dan dalâlah (tunjukan makna). ${ }^{12}$ Pendapat ini sebenarnya bukanlah pendapat baru, bahkan mayoritas dari kalangan ulama Hadis dan Fikih berpendapat bahwa hadis Âhâd berstatus zhanni al-tsubût bukan qathi al-tsubût kecuali sebagian besar dari ulama Hanabilah dan Zhahiriyah. ${ }^{13}$ Pendapat al-Ghazâlî ini juga didukung oleh syeikh

${ }^{10} \mathrm{Ibid}$.

${ }^{11} \mathrm{Ibid}$.

${ }^{12}$ Muhammad al-Ghazali, Turâtsunâ al-Fikri fî̀ Mîzân al-Syar' wa al-'Aql, (USA: The International Institute of Islamic Thought, 1996), h. 152. Lihat juga buku lain karya Muhammad al-Ghazali, Kaifa Nata'âmal ma'a al-Qur'ân, (Kairo: Dâr al-Wafâ, 1993), h. 112.

${ }^{13}$ Beberapa ulama terkenal yang membenarkan dan berpedoman kepada pendapat ini adalah al-Juwayni, Abu Hâmid al-Ghazali, al-Bazdawi, al-Isnawi, al-Nawawi, al-Khatîb alBaghdâdi, al-Baqilâni dan al-'Irâqi. Lihat Abu Hâmid al-Ghazali, al-Mushtashfa min 'Tlm al-Ushûl, (Beirut, Dâr Ihya' al-Turâts al-'Arabi, 1997), h. 116. Lihat juga Imam al-Juwayni Abu al-Ma'aly 
Yusuf al-Qaradhawi mengatakan bahwa aqidah harus berdasarkan dalil yang kuat yaitu al-Qur'ân dan hadis mutawatir. Bukan atas dasar dalil yang bersifat žhanni. Oleh karena itu pula, hadis-hadis Âhâd walaupun shahih, tidak menghasilkan kepastian atau 'ilm al-yaqîn, kecuali hadis yang berstatus mutawatir saja yang dapat menghasilkan kepastian dan 'ilm al-yaqîn. ${ }^{14}$

Jumhur ulama Hadis, Ushul Fikih, dan Ushuluddin sebelumnya telah menegaskan bahwa hadis Âhâd yang berstatus shabîh hanya menghasilkan ilmu žhanni kecuali hadis Âhâd yang memiliki qorinah (indikator) yang mengindikasikan kekuatan lebih pada hadis tersebut. Pendapat ini ditolak oleh sebagian ulama hadis dan mayoritas ulama Hanâbilah. ${ }^{15}$ Diantara ulama yang mengatakan hadis Âhâd menghasilkan kepastian (qathı) adalah Ibnu al-Shalâh, Ibnu Hazm, al-Husein alKarâbisî, al-Hârits bin Asad al-Muhâsibi, dan Syeikh al-Albânî. ${ }^{16}$

Syeikh M. al-Ghazâlî dalam kitabnya al-Sunnah al-Nabawiyah baina Abl alFigh wa Abl al-Hadits mengatakan bahwa sejauh penelitiannya di Universitas alAzhar dalam kurun waktu yang relatif panjang, ia berkesimpulan bahwa hadis Âhâd menghasilkan ilmu zhanni dan merupakan dalil bagi hukum syara' selama tidak ditemui dalil lain yang lebih kuat daripadanya. Ia menolak secara totalitas pendapat yang mengatakan hadis Âhâd menghasilkan ilmu yaqin seperti halnya mutawatir. Menyamakan hadis Âhâd dengan mutawatir merupakan kekeliruan nyata dalam alur pikiran sehat. ${ }^{17}$

Al-Ghazâlî dalam Nažbarât fî al-Qur'ân menukil pendapat M. Rasyid Ridha yang menegaskan bahwa tidak dapat dipungkiri terdapat perbedaan kondisi antara permasalahan yang merujuk kepada al-Qur'ân dan yang merujuk kepada hadis Âhâd. Oleh sebab itu para ulama fikih menyimpulkan bahwa seorang muslim yang mengingkari isi kandungan teks al-Qur'ân dinyatakan kafir. Adapaun yang mengingkari selain itu, maka dilihat pada latar belakang pengingkarannya.

Abd al-Malik bin Yusuf, al-Burbân fì 'Ushûl al-Fiqh, (Kairo: Dâr al Wafa', 1992), tahqî́q Dr. Abd. Al-'Azhim Mahmûd ad-Dîb, jld. 1, h. 389; Mahmud Syaltut, al-Islâm; 'Aqidah wa Syari'ah, (Kairo: Dâr al-Shurûq, 1980), h. 60.

${ }^{14} \mathrm{M}$. Yusuf al-Qardhawi, al-Marizi'iyyah al-Ulyâ fì al-Islâm, (Kairo: Maktabah Wahbah, 1998), h. 115-125. Bandingkan dengan M. al-Ghazali, Turâtsunâ al-Fikri..., op. cit., h. 170.

${ }^{15}$ Mahmûd al-Tahhan, op. cit., h. 22; Ibnu Hazm, al-Ihkâm fì Ushûl al-Abkâm, (Kairo: al'Asimah, 1934), jld. 1, h. 107; Ibnu Hajar al-'Asqalânî, Nų̧hat al-Ną̧dar fi taudhîh Nukbbah alNaz̧har, (Kairo: Dâr al-Arqam, 1996), h. 125.

${ }^{16}$ Ibnu Hazm, al-Ihkâm fí Usbûl, h. 97; Ibnu al-Shalâh, Muqaddimah Ibnu al-Salâh, (Kairo: Muassasât al-Kutub al-Thaqafiyyah, 1997), h. 44; Muhammad Nasir al-Din al-Albâny, Silsilât alAhadits al-Sabîhah, (Kairo: al-Maktab al-Islami, 1998), jld. 1, h. 159.

${ }^{17}$ Muhammad al-Ghazali, al-Sunnab al-Nabawiyyah baina al-Fiqh wa Abl al-Hadîts, (Kairo: Dâr al-Syurûq, 1996), h. 74-75. Lihat juga kitabnya yang lain, al-Tharî́ min Hunâ, (Kairo: Dâr alBashir, 1987), h. 63; dan juga kitabnya, Naz̧harât fí al-Qur'ân, (Kairo: Dâr al-Nahdhah, 1996), h. 143. 
Sebagaimana ditemukan beberapa mujtahid menghasilkan pendapat yang berseberangan dengan isi teks hadis shahih karena dilatar belakangi argumentasi tertentu pula. Pendapat sebagian mujtahid itu bertentangan pula dengan pedapat kebanyakan ulama pada masanya, namun tidak seorangpun dari ulama pada masa itu yang mengkafirkannya. ${ }^{18}$

M. al-Ghazâlî merasa heran ketika melihat sahabatnya Syeikh M. Abu Syahbah marah kepada orang yang menolak hadis lalat dalam kitab Shahîh alBukhârî dengan alasan bahwa hal tersebut masuk dalam kategori permasalahan keyakinan (al-yaqiniyât). Al-Ghazâlî membantah pendapat Syeikh Abu Syahbah tersebut dengan menyatakan ketika belajar di Universitas al-Azhar dahulu diajarkan bahwa hadis Âhâd hanya menghasilkan $a$ ə̧h-z̧hann ar-râjih. Mustahil para ulama yang mengajarkan Ulum al-Hadìts tersebut berdusta atau sengaja berbohong. ${ }^{19}$ Menurutnya, pendapat yang mengatakan hadis Âhâd memiliki kepastian tidak pernah ditemukan pada zaman salaf. Bahkan pendapat yang mengatakan bahwa hadis Âhâd memberikan keyakinan berasal dari kedangkalan berfikir dan dapat merusak ajaran Islam itu sendiri. ${ }^{20}$

M. al-Ghazâlî berpendapat bahwa banyak ulama tidak mengamalkan hadis shahih disebabkan alasan tertentu. Para sahabat Nabi saw sebagai perawi yang paling tinggi nilainya juga melakukan kesilafan seperti Ibnu 'Umar yang mengatakan Nabi saw melaksanakan umrah sebanyak empat kali salah satunya di bulan Rajab. Pernyataan Ibnu Umar tersebut kemudian dikoreksi oleh 'Aisyah. Umar dan anaknya pernah melakukan kekeliruan ketika meriwayatkan hadis pengazaban mayat kemudian dikoreksi oleh Ibnu 'Abbas dan 'Aisyah. Ibnu Mas'ud pernah menyatakan tayammum tidak wajib dan Ibnu 'Umar pernah mengatakan bahwa shalat dhuha itu bid'ah. ${ }^{21}$

Menurut M. al-Ghazâlî hadis Âhâd hanya berguna sebagai penjelasan dan tafsiran kepada pokok permasalahan akidah. Ia menegaskan bahwa hadis Âhâd tidak dapat menjelaskan bagian yang bersifat umum dan mutlaq dalam al-Qur'ân, bahkan hanya hadis shahih yang masyhur saja yang bisa menafsirkan al-'am dan mutlaq yang terdapat dalam al-Qur'an. ${ }^{22}$

Menurut penelitian, hadis Âhâd kuat akan tetapi membutuhkan hadis lain yang menguatkannya sehingga dapat menghasilkan kesimpulan yang pasti. Hadis

${ }^{18}$ Ibid.

${ }^{19}$ M. al-Ghazali, Turathuna al-Fikri..., h.168.

${ }^{20}$ M. al-Ghazali, al-Sunnah al-Nabawiyyah..., h. 79; M. al-Ghazali, Sirr Ta'akbkbur al-'Arab wa al-Muslimin, (Kairo: Dâr al-Nahdah, 1996) h. 53.

${ }^{21}$ M. al-Ghazali, Kaifa Nata'âmal ma'a al-Qur'ân..., h.113-114; M. al-Ghazali, Dustûr alWabdah al-Thaqafiyyah baina al-Muslimin, (Damaskus: Dâr al-Qalam, 1986), h. 70; M. al-Ghazali, alSunnah al-Nabawiyyah..., h.74-75.

${ }^{22}$ M. al-Ghazali, al-Sunnab al-Nabawiyyah..., h. 19 dan lihat juga M. al-Ghazali, Kaifa Nata'âmal ma'a al-Qur'ân..., h. 115. 
Ibnu Mas'ud dan Dzu al-Yadain dalam riwayat al-Bukhârî sebagai bukti dalam permasalahan ini. Berikut teks hadisnya:

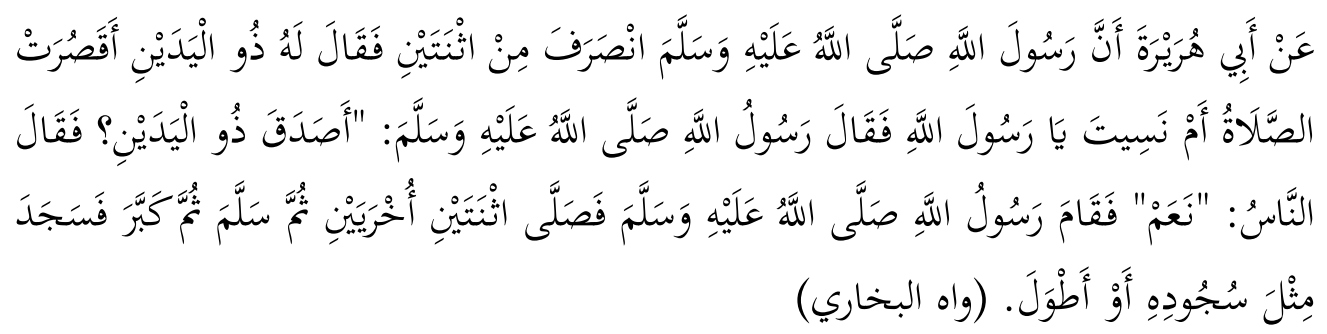

Abu Hurairah meriwayatkan bahwa Nabi saw beranjak dari tempatnya setelah shalat dua rakaat. Kemudian D₹u al-Yadain berkata: "Wabai Rasulullah, apakah shalat diqashar atau tuan lupa?" Rasulullah saw bersabda: "Apakah benar apa yang dikatakan Dzu al-Yadain?" para sahabat menjawab: "Benar ya Rasulullah". Maka Rasulullah saw berdiri dan shalat dua rakaat lagi kemudian salam. ${ }^{23}$

Dari hadis di atas jelas terlihat bahwa hadis Âhâd adalah hujjah yang digunakan dalam furu' al-syariah selama tidak ditemukan dalil lain yang lebih kuat. Hanya saja hadis Âhâd tersebut tidak sampai menghasilkan keyakinan (qath'i) sehingga bisa digunakan sebagai argumentasi dalam pokok aqidah. ${ }^{24}$

\section{Metode Pemahaman Hadis Syeikh Muhammad al-Ghazali}

Sikap para pemikir kontemporer terhadap sunnah harus dipahami dan dibandingkan dengan melihat bagaimana pola dasar pemikiran para pemikir klasik, menurut ilmu kritik hadis klasik, kesahihan hadis ditentukan oleh tiga kriteria, pertama sejauh mana sebuah riwayat dapat dikuatkan oleh riwayat lain yang identik dari periwayat lain, kedua, keadilan dan kedhabitan periwayat, ketiga, kesinambungan dengan rantai periwayatan. Hadis seperti ini disebut mutawatir.

${ }^{23}$ Imam al-Bukhârî Muhammad bin Ismâ’̂̂l bin Ibrahim bin al-Mughîrah al-Ju’fi (w. 256 H), al-Jâmi' al-Shabîh al-Musnad min Hadîts Rasulillah saw wa sunanibi wa ayyamibi atau lebih dikenal Shabîh al-Bukhârî, dalam Kitab Akhbâr Âhâd, bab Mâ Jâ' fì Ijâzah Khabar al-Wabîd al-Shadûq fî alAdhan wa al-Shalâh wa al-Sawm wa al-Farâidh wa al-Ahkâm, hadis no. 6709. Dalam hadis ini dijelaskan bahwa Rasulullah bertanya kepada para sahabat tentang kebenaran kata-kata Dzul Yadain untuk mendapatkan kepastian. Sekiranya kata-kata Dzul Yadain adalah pasti, tidak perlu lagi Rasulullah bertanya kepada para sahabat untuk memastikan kebenaran kata-katanya itu. Dengan itu, jelas bahwa hadis Âhâd adalah argumentasi yang digunakan dalam furû' al-syari'ah selagi tidak ada dalil yang lebih kuat tetapi tidak bertaraf shahih sehingga menguatkan aspek akidah.

${ }^{24}$ M. al-Ghazali, Kaifa Nata'âmal ma'a al-Qur'ân..., op. cit., h.168. 
Adapun mengenai hadis abad, para ulama klasik mensyaratkan harus melewati lima tahap pengujian. ${ }^{25}$ Di antaranya adalah;

1. Kesinambungan periwayat (ittishâl).

2. 'Adâlah periwayat, yaitu mereka harus menjunjung tinggi agama, dan tidak melakukan dosa-dosa besar.

3. Akurasi proses periwayatan, seperti periwayat tidak boleh ceroboh atau diketahui memiliki daya ingat yang lemah.

4. Bebas dari syud₹ûdฆ, yaitu kontradiksi dengan sumber-sumber yang lebih dapat dipercaya.

5. Bebas dari cacat-cacat penyimpangan ('illat qadbihah), yaitu ketidaktepatan dalam melakukan periwayatan.

Aturan ini merupakan bentuk ringkas dari metode yang digunakan mubadditsîn untuk membedakan hadis-hadis autentik. Penerapan sistematis metode ini tampak pada kitab-kitab besar hadis sahih, yang merupakan puncak keilmuan hadis klasik. ${ }^{26}$

Namun semua ini berubah pada masa modern, ketika tekanan untuk mereformasi, mereformulasi, dan mengenalkan kembali hukum Islam muncul dan membuat studi hadis relevan kembali. Setelah pertengahan abad kesembilan belas, pada prakteknya mazhab-mazhab klasik digantikan oleh peraturan hukum sekuler yang diilhami barat, dan kebanyakan masyarakat Muslim ditantang oleh gerakan seperti hadis salafiyah. Akibat tumbangnya dominasi mazhab-mazhab hukum klasik, terbukalah ruang bagi pengkajian kembali sumber-sumber hukum Islam dan kedudukan sunnah. Sejak terbebasnya masyarakat Muslim dari dominasi kolonial setelah tahun 1940-an, gerakan untuk memperkenalkan kembali hukum Islam dalam bentuk tertentu telah memunculkan urgensi praktis untuk mempertanyakan sumber-sumber syari'ah, dan metode untuk menghidupkan kembali syari'ah.

Di kalangan mereka mendorong gerakan untuk kembali ke hukum yang berbasiskan syari'ah dalam bentuk tertentu, ada anggapan implisit bahwa tidak mungkin melangkah balik dalam waktu dan kembali kepada hukum Islam dalam bentuk klasiknya. Hal ini bisa dilakukan dengan interpretasi dan pemahaman ulang tentang bagaimana penilaian kembali hadis.

Menurut Muhammad al-Ghazali, ada lima kriteria untuk menguji kesahihan hadis; tiga berkaitan dengan sanad dan dua berkaitan dengan matan. Tiga kriteria yang berkaitan dengan sanad adalah; 1 . Periwayat $d h a ̂ b i t, 2$. Periwayat ádil, dan 3. Poin satu dan dua harus dimiliki seluruh rawi dalam sanad. ${ }^{27}$ Berbeda

${ }^{25}$ Muhammad 'Ajaj Al-Khathib, Ushâl al-Hadîts 'Ulumubu wa Musthalâbubu, (Kairo: Dâr al-Fikr, t.th), h. 305.

${ }^{26}$ Syuhudi Ismail, Kaidab Kesabihan Sanad Hadis (Jakarta: Bulan Bintang, 1995), h. 111.

${ }^{27}$ M. al-Ghazali, al-Sunnah al-Nabawiyah..., h. 54 
dengan pandangan mayoritas ulama hadis klasik, Muhammad al-Ghazâlî tidak memasukkan ketersambungan sanad sebagai kriteria kesahihan hadis, bahkan unsur ketiga sebenarnya sudah masuk ke dalam kriteria poin dua. Dalam hal ini Muhammad al-Ghazâlî tidak memberikan argumentasi sehingga sangat sulit untuk ditelusuri, apakah ini merupakan salah pemikiran atau ada unsur kesengajaan. ${ }^{28}$

Adapun dua kriteria yang berkaitan dengan matan, adalah:

1. Matan hadis tidak syadz yaitu salah seorang atau beberapa periwayatnya bertentangan periwayatannya dengan periwayat yang lebih akurat dan lebih dapat dipercaya.

2. Matan hadis tidak mengandung illat qadhihah yaitu cacat yang diketahui oleh para ahli hadis sehingga mereka menolak periwayatannya. ${ }^{29}$

Menurut M. al-Ghazâlî untuk merealisasikan kriteria-kriteria tersebut, maka diperlukan kerjasama antara mubaddits dengan berbagai ahli-ahli lain termasuk fuqaha', mufassir, ushûliyûn dan ahli ilmu kalam. Mengingat materi hadis ada yang berkaitan dengan akidah, ibadah, mu'amalah sehingga memerlukan pengetahuan dengan berbagai ahli tersebut. ${ }^{30}$ Atas dasar itulah, al-Ghazâlî menawarkan empat metode pemahaman hadis atau prinsip-prinsip dasar yang harus dipenuhi ketika hendak berinteraksi dengan sunnah, supaya dihasilkan pemahaman yang sesuai dengan ajaran agama. Diantaranya adalah:

\section{a. Pengujian dengan al-Qur'ân}

Syeikh M. al-Ghazâlî mengecam keras orang-orang yang memahami secara tekstual hadis-hadis yang sahih sanadnya, namun matannya bertentangan dengan al-Qur'ân. Pemikiran tersebut dilatarbelakangi adanya keyakinan tentang kedudukan hadis sebagai sumber otoritas setelah al-Qur'ân. Tidak semua hadis orisinal dan tidak semua dipakai secara benar oleh periwayatnya. al-Qur'ân menurut Muhammad al-Ghazâlî adalah sumber pertama dan utama dari pemikiran dan dakwah, sementara hadis adalah sumber kedua. Dalam memahami al-Qur'ân hadis sangat penting, karena hadis adalah penjelas teoritis dan praktis bagi al-Qur'ân. Oleh karena itu, sebelum melakukan kajian tentang matan hadis, perlu upaya intensif memahami al-Qur'ân sebagaimana pernyataannya: "Jelas bahwa untuk menetapkan kebenaran suatu hadis dari segi matannya diperlukan ilmu yang mendalam tentang al-Qur'ân serta kesimpulan-kesimpulan yang dapat

${ }^{28}$ Suryadi, Metode Pemahaman Hadis Nabi (Telaah Atas Pemikiran Muhammad Al-Ghazââ Dan Yusuf Al-Qardhawi). Ringkasan Disertasi, (Yogyakarta: Program Pasca sarjana UIN Sunan Kalijaga, 2004), h.6

${ }^{29}$ Ibid.

${ }^{30}$ Ibid. h. 20. 
ditarik dari ayat-ayatnya, baik secara langsung atau tidak". ${ }^{31}$ Pengujian dengan ayat al-Qur'ân ini mendapat porsi yang lebih dari M. al-Ghazâlî dibanding dengan tiga kriteria lainnya. Bahkan menurut Quraisy Shihab bahwa meskipun al-Ghazâlî menetapkan empat tolak ukur, kaidah nomor pertama yang dianggap paling utama menurutnya. ${ }^{32}$

Penerapan kritik hadis dengan pengujian al-Qur'ân diarahkan secara konsisten oleh Muhammad al-Ghazali. Oleh karena itu tidak sedikit hadis yang dianggap sahih misalnya terdapat dalam kitab sahih bukhari dan muslim, dianggap dhaif oleh Muhammad al-Ghazali, bahkan secara tegas menyatakan bahwa dalam hal-hal yang berkaitan dengan kemaslahatan dan mu'amalah duniawiyah, akan mengantarkan hadis yang sanadnya dhaif, bila kandungan matannya sesuai dengan prinsip-prinsip ajaran al-Qur'ân, dari pada hadis yang sanadnya sahih tapi kandungan matannya tidak sesuai dengan inti dari ajaran-ajaran al-Qur'an.

\section{b. Pengujian dengan Hadis}

Pengujian ini memiliki pengertian bahwa matan hadis yang dijadikan dasar argumen tidak bertentangan dengan hadis mutawatir dan hadis lainnya yang lebih sahih. Menurut Muhammad al-Ghazâlî hukum yang berdasarkan agama tidak boleh diambil hanya dari sebuah hadis yang terpisah dengan hadis yang lainnya, tetapi setiap hadis harus dikaitkan dengan hadis lainnya, kemudian hadis-hadis yang tersambung itu dikomparasikan dengan apa yang ditunjukkan oleh $\mathrm{Al}$ Qur'an.

\section{c. Pengujian dengan Fakta Historis}

Suatu hal yang tidak bisa dipungkiri, bahwa hadis muncul dan berkembang dalam keadaan tertentu, yaitu pada masa Nabi Muhammad hidup, oleh karena itu hadis dan sejarah memiliki hubungan sinergis yang saling menguatkan satu sama lain. Adanya kecocokan antara hadis dengan fakta sejarah akan menjadikan hadis memiliki sandaran validitas yang kokoh. Demikian pula sebaliknya, bila terjadi penyimpangan antara hadis dan sejarah, maka salah satu diantara keduanya diragukan kebenarannya.

\section{d. Pengujian dengan Kebenaran Ilmiah}

Pengujian ini dapat diartikan bahwa setiap kandungan matan hadis tidak boleh bertentangan dengan teori ilmu pengetahuan atau penemuan ilmiah, memenuhi rasa keadilan atau tidak bertentangan dengan hak asasi manusia. Oleh karena itu, adalah tidak masuk akal jika hadis nabi mengabaikan rasa keadilan. Menurut Al-Ghazali, bagaimanapun sahihnya sanad sebuah hadis, jika matan

${ }^{32}$ Ibid. h. 29 
informasinya bertentangan dengan prinsip-prinsip hak asasi manusia, maka hadis tersebut tidak layak dipakai.

\section{Hadis-Hadis Âhâd yang Dikritik oleh M. al-Ghazali}

Dari karya-karyanya dapat ditemukan beberapa hadis yang dikritik (naqd) oleh M. al-Ghazâlî dengan menggunakan pendekatan rasio dan kenyataan empiris sekalipun diantaranya merupakan hadis dengan status shahîh. Berikut pembahasannya:

\section{Hadis mengenai Lalat}

Hadis mengenai lalat ini diriwayatkan oleh Imam al-Bukhari, Imam Abu Daud, ${ }^{33}$ dan Ahmad bin Hanbal. ${ }^{34}$ Berikut teks hadisnya:

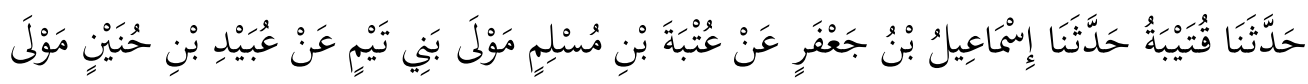

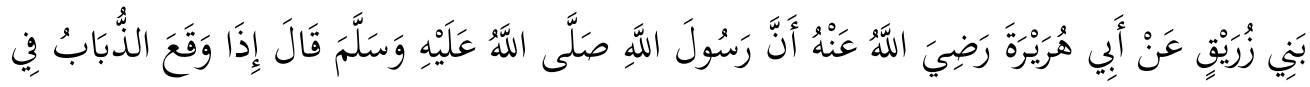

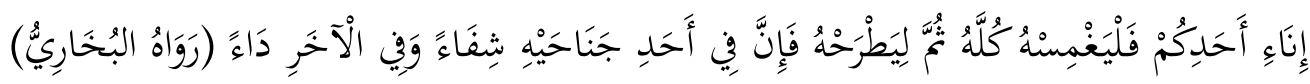

Telah berkata kepada kami Qutaibah, telah berkata kepada kami Ismail bin Ja'far dari 'Utbab bin Muslim maula bani Taim dari 'Ubaid bin Hunain maula bani Zuraiq dari Abu Hurairah ra bahwa Rasulullah saw bersabda: "Apabila lalatjatuh dalam bejana minumanmu

33 Adapun teks hadis dalam Sunan Abu Daud adalah sebagai berikut:

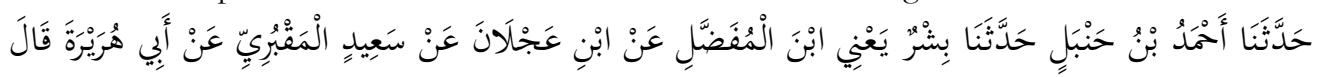

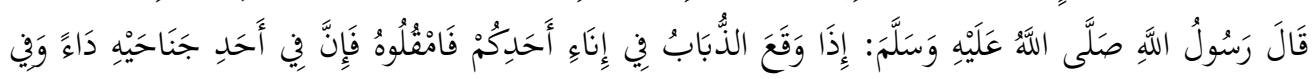

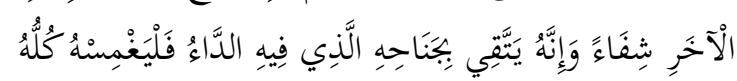

Hadis ini diriwayatkan oleh Imam Abu Daud Sulaiman bin al-'Ats'ats bin Ishaq al-Azdi alSisjistani (w. $275 \mathrm{H}$ ) dalam sunannya sebagaimana yang disyarah oleh Muhammad Syams al-Haq al-'Azhîm Âbâdî Abu Thaiyyib, 'Aun al-Ma'bûd syarb Sunan Abi Daud, (Beirut: Dâr al-Kutub al'Ilmiyah: 1415 H) jld. 10, h. 323, hadis no. 3346.

34 Berikut teks hadis dalam Musnad Imam Ahmad:

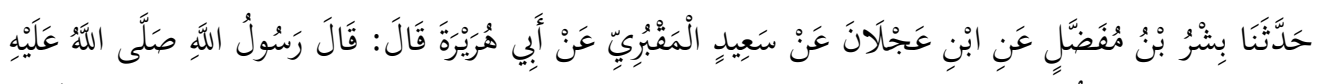

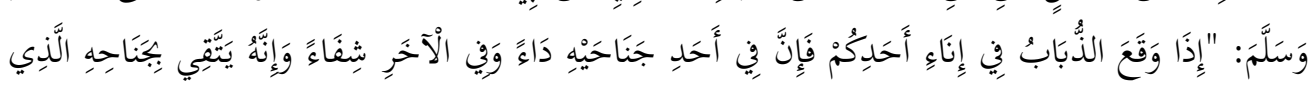

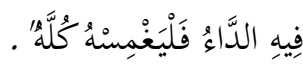

Imam Ahmad bin Hanbal al-Harrâni $(240 \mathrm{H})$ meriwayatkan hadis ini dalam musnadnya, al-Musnad, (Muassasah ar-Risâlah: Beirut, 1999) cet.II, dengan tahqîq syeikh Syu'aib al-Arnaûth, jld. 14, h. 385, hadis no. 6844 . 
maka celupkanlah ia semuanya, kemudian keluarkan dan bejana itu. Sesunggubnya di salah satu sayapnya terdapat obat dan sayap lain terdapat racun"."35

Dalam kitab Turâtsunâ al-Fikeri fì Mîrân al-Syara' wa al-'Aql, syeikh alGhazâlî menegaskan bahwa hadis lalat dalam shahih al-Bukhârî merupakan hadis shahih, akan tetapi hal ini bukanlah perkara yang qath'i. Pernyataan ini menimbulkan kontroversi sehingga bermunculanlah krtitikan dan tudingan terhadapnya sebab dianggap telah menolak hadis shahih. Dalam kitab Sirr Ta'akbhur al-'Arab wa al-Muslimin, ia menjelaskan bahwa hadis lalat tidak berkaitan dengan permasalahan akidah dan hukum taklifi. ${ }^{36}$

Dalam kitab Qadzẩif al-haqq, ia menegaskan bahwa menolak salah satu hadis Âhâd berdasarkan argumentasi yang kuat tidaklah sampai menghancurkan aqidah seseorang yang berada dalam hatinya. Sebab, sekalipun hadis Âhâd itu shahih, akan tetapi tetap saja bersifat azh-zhann al-ílmi. Dalam hal itu dapat diabaikan (hadis Âhâd) jika ditemukan hadis yang lebih kuat atau lebih rajah. Hadis Âhâd bukanlah sumber aqidah dan hukum yang pasti, namun berfungsi sebagai penyempurna kajian ilmiah. Sekiranya seorang muslim mengatakan bahwa ia menolak hadis lalat ini, maka tidaklah karena itu ia menjadi kafir. M. al-Ghazâlî menegaskan bahwa tidak seorangpun dari para ulama yang mengatakan bahwa rukun Islam meliputi iman kepada Allah, hari akhirat dan mencelupkan lalat dalam minuman apabila terjatuh ke dalamnya. ${ }^{37}$

\section{Hadis mengenai Pengharaman Lagu dan Musik.}

Diantara permasalahan yang menimbulkan kontroversi adalah pendapat Muhammad al-Ghazâlî yang membolehkan lagu dan musik. Ia menolak pendapat yang mengatakan semua lagu dan alat musik adalah haram. Pendapat ini berdasarkan tidak ditemukannya satu hadis shahih pun yang mengharamkan hal tersebut.

Al-Bukhârî meriwayatkan hadis yang meriwayatkan sebuah hadis secara mu'allaq yang menyatakan bahwa kelak akan ditemukan sekelompok manusia yang menghalalkan hiburan atau lagu, berikut teks hadisnya:

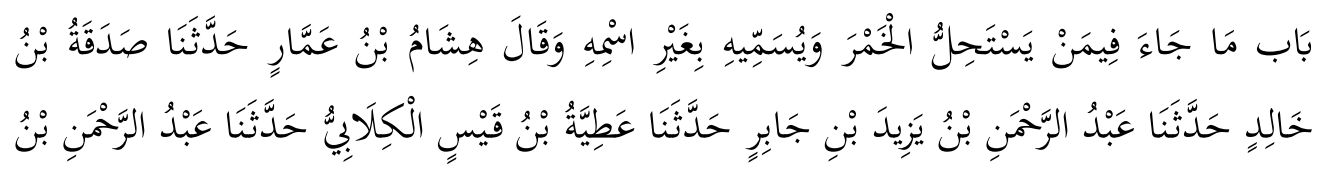

${ }^{35}$ M. al-Ghazali, Sirr Ta'akbkhur al-'Arab wa al-Muslimin, (Kairo: Dâr Nahdah, 1996), h.102. lihat juga kitab syeikh M. al-Ghazali, Turâtsunâ al-Fikri..., h.168.

${ }^{36}$ M. al-Ghazali, Qadzẩif al-Haqq, (Beirut: Dâr al-Qalam, 1997), h. 148-149.

${ }^{37}$ Imam Al-Bukhârî, Sahîh Al-Bukhârî, Kitab ad-Diyah; bab La Yuqtal Muslim bi Kafir, hadis no. 6404; Imam Abu Daud, Sunan Abi Dawnd, Kitab al-Diyat; bab Ayuqad al-Muslim Bi Kafir, hadis no. 4531. 


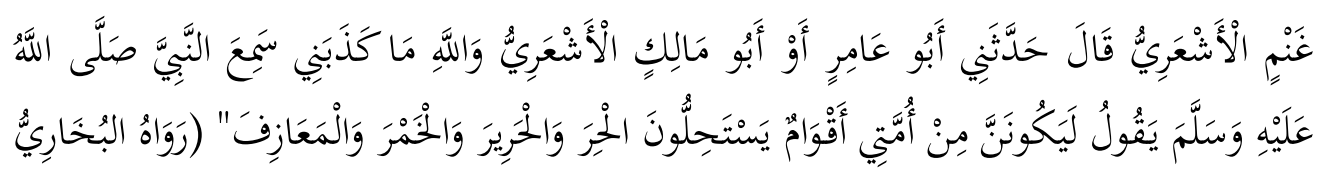

"Bab berkenaan tentang orang yang menghalalkan khamar dan menyebutnya dengan nama yang lain. Berkata Hisyâm bin 'Ammâr berkata kepada kami Shadaqah bin Khalid berkata kepada kami Abdurrabman bin Yazîd bin Jâbir berkata kepada kami 'Athiyah bin Qais al-Kilâbi berkata kepada kami Abdurrahman bin Ghanmin al-Asy'ari berkata: telah berkata kepada saya Abu 'Âmir atau Abu Mâlik al-'Asy'ari: "Demi Allah tidak pernah ia berdusta kepada saya" bahwa ia mendengar Nabi saw bersabda: "Sungguh akan muncul dari kalangan umat ku golongan yang menghalalkan peræinaan, sutra, minuman keras dan alat-alat musik." (HR. al-Bukhârî mu'allaq). ${ }^{38}$

Ibnu Hajar al-'Asqalânî menegaskan bahwa hadis mu'allaq ${ }^{39}$ yang disebutkan Imam al-Bukhârî ini adalah shahîh muttashil, ${ }^{40}$ sebagaimana yang diriwayatkan oleh Imam al-Ismâ'îly dalam al-Mustakhraj, ${ }^{41}$ al-Thabrânî dalam

${ }^{38}$ Imam Al-Bukhârî Muhammad bin Ismâ’̂̂l bin Ibrahim bin al-Mughîrah al-Ju’fi (w. 256 H), al-Jâmi' al-Shabîh al-Musnad min Hadîts Rasulillab shalla Allabu 'alaibi wa sallam wa sunanibi wa ayyamibi, atau lebih dikenal dengan nama Sabîh al-Bukebârî, dalam Kitâb al-Asyribah, pada bab fì man Yastabil al-Khamr, hadis no. 5595. Lihat juga M. al-Ghazali, al-Sunnab al-Nabawiyyah..., h. 84.

${ }^{39}$ Hadis ini adalah hadis mu'allaq. Yaitu hadis yang permulaan sanadnya dihilangkan, baik yang dihilangkan itu hanya satu atau lebih secara berurutan, walaupun akhir sanadnya dicantumkan. Hadis mu'allaq termasuk dalam golongan hadis daif munqati' dan ditolak oleh mayoritas ahli hadis. Hisyam bin Ammar dianggap sebagai shadûq oleh mayoritas ahli hadis. Ibnu Hajar al-'Asqalani dalam al-Taqrîb mengatakan Hisyam bin Ammar adalah shadûq muqri' tetapi ada meriwayatkan hadis dari Ma'ruf al-Khayath yang tidak tsiqah. Dalam kitab Taghlìg al-Ta'lìq, Ibnu Hajar menyebutkan sembilan sanad yang bersambung untuk hadis ini agar menjelaskan status hadis ini dan ia berkesimpulan bahwa dengan banyaknya sanad, maka hadis ini shahih. Lihat Muhammad 'Ajjầj al-Khatîb, Ushûl al-Hadîts 'Ulûmubu wa Mustalâbubu, (Beirut: Dâr al-Fikr, 1989), h. 357. Lihat juga Ibnu Hajar al-'Asqalânî Ahmad bin Ali bin Hajar Abu Fadhl (w. 852 H), Tagbliq al-Ta'lì 'Ala Shahîh al-Bukhârî, (Beirut: al-Maktab al-Islâmî, t.th.), jld. 5, h. 17-22.

${ }^{40}$ Ibnu Hajar al-Asqalânî, Taghliq al-Ta'lìq 'Ala, jld. 10, h. 66-67.

${ }^{41}$ Riwayat Imam al-Ismầ̂ly ini disebutkan Ibnu Hajar dalam kitabnya syarb shahîh alBukbârî. Lihat Ibnu Hajar al-'Asqalânî, Fath al-Bârî syarh Shahîh al-Bukhârî, (Beirut: Dâr al-Ma'rifah, 1379 H), jld. 10, h. 54 . 
kitab Musnad al-Syâmiyîn, ${ }^{42}$ Abu Daud al-Thayâlisî dalam Musnad, ${ }^{43}$ Imam Ahmad dalam Musnad, ${ }^{44}$ dan Ibnu Hibbân dalam al-Shahîh. ${ }^{45}$

Menurut Ibnu Taimiyah, Ibnu al-Jauzi, Ibnu Qayyim al-Jauziyah, Ibnu Shalâh dan Syeikh al-Albâny mengharamkan lagu dan musik berdasarkan hadis

42 Berikut ini teks hadis dalam Mưjam al-Thabrânî:

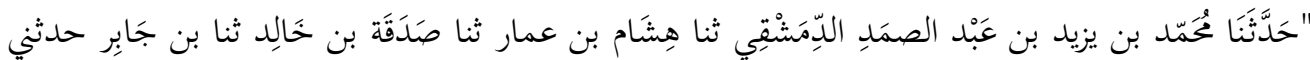

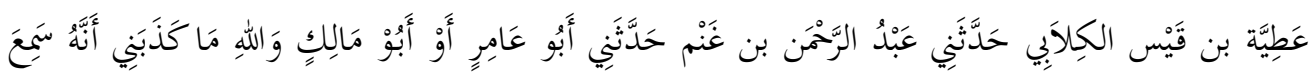

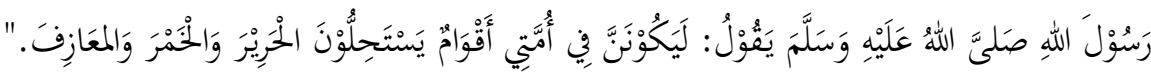

Hadis ini diriwayatkan oleh Imam al-Thabrani Sualiman bin Ahmad bin Ayyub Abu al-Qasim dalam Musnad al-Syâmiyîn, (Muasasah ar-Risâlah: Beirut, 1984) cet. I, jld. 1, h. 344, hadis no. 588.

${ }^{43}$ Berikut ini teks hadis dalam Musnad Abu Daud al-Thayâlisî:

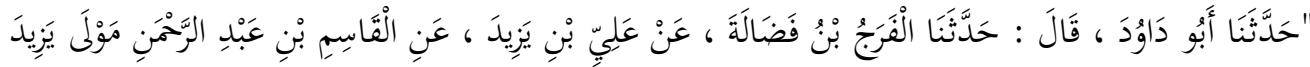

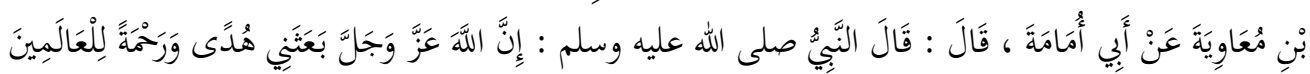

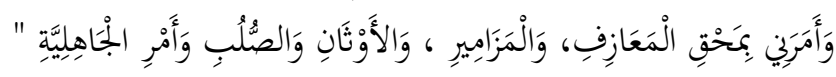

Hadis ini diriwayatkan oleh Imam Abu Daud al-Thayâlisî Sulaiman bin Daud bin al-Jârûd (w. 204 H), Musnad al-Thayâlisî, (Riyadh: Dâr al-Hijrah, 1999), cet. I, jld. 2, h. 454, hadis no. 1230.

${ }^{44}$ Imam Ahmad meriwayatkan hadis ini dalam musnadnya dengan sanad dan matan yang hampir sama dengan periwayatan Abu Daud al-Thayâlisî. Lihat Imam Ahmad bin Hanbal alHarrâni $(240$ H), al-Musnad, (Beirut: Muassasah ar-Risâlah, 1999) cet.II, dengan tahqî́q syeikh Syu'aib al-Arnaûth, jld. 36, h. 646, hadis no. 22307.

${ }^{45}$ Berikut ini teks hadis dalam Shahîh Ibnu Hibbân:

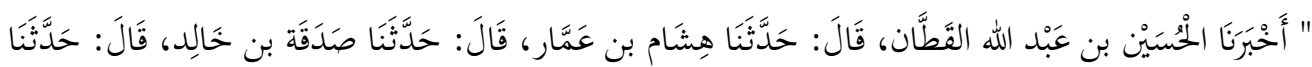

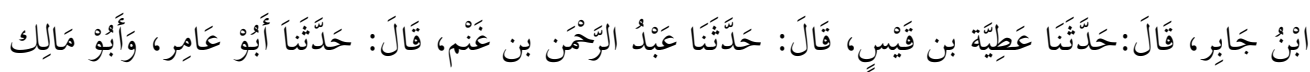

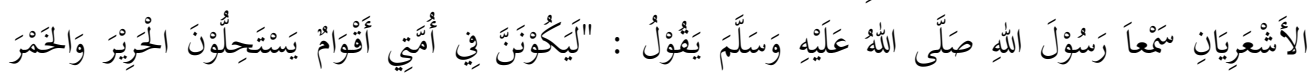
وَالْمَعَازفِ

Hadis ini diriwayatkan oleh Imam Ibnu Hibbân Muhammad bin Hibbân bin Ahmad bin Hibbân al-Tamîmy Abu Hâtim ad-Dârimî al-Bustî (w. 354 H) dalam Shabîh Ibnu Hibbân (Muassasah ar-

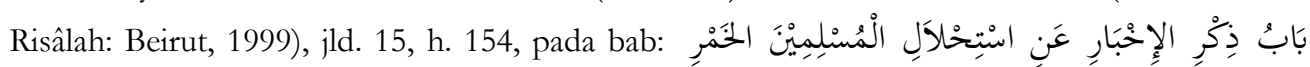
وَالَْعَازفِِ فِي آخِرِ الزَّمَانِ, hadis no. 6754. 
ini. ${ }^{46}$ Imam Abu Hamid al-Ghazâlî (w. 505 H) mengikut pendapat Imam al-Syâfíi bahwa lagu yang baik adalah baik sedangkan lagu yang buruk adalah buruk. ${ }^{47}$

Ibnu Hazm azh-Zhâhirî menganggap lagu dan nyanyian merupakan perkara yang mubah dan menolak hadis tersebut di atas serta menyatakan bahwa tidak ditemukan satu hadis shahih pun yang dengan tegas mengharamkan nyanyian dan alat-alat musik. Menurutnya, semua hadis yang mengharamkan nyanyian dan musik adalah palsu. Sekiranya terdapat hadis yang shahih dari jalur sanad lain yang diriwayatkan oleh perawi tsigah pula, maka Ibnu Hazm tidak akan menolaknya. Akan tetapi karena tidak ditemukan hadis yang kuat dapat dijadikan landasan, maka Ibnu Hazm mengemukakan pendapatnya yang membolehkan nyanyian dan alat musik dengan begitu tegas tanpa keraguan sedikitpun. Beliau menganggap Sadaqah bin Khalid seorang yang daif. Selain itu, perkataan 'aw' antara Abu Musa al-Ash'ari dan Abu Malik al-Ash'ari dalam sanad ini menunjukkan keraguan yang melemahkan martabat kesahihan sanad hadis di atas. $^{48}$

Menurut Syeikh M. al-Ghazâlî boleh jadi dipahami bahwa diharam musik disebabkan faktor lain yaitu kegiatan tambahan yang dilakukan sambil mendengarkan musik dan nyanyian seperti mendengar musik sambil meminum arak atau perbuatan lain yang mengarah kepada zina dan maksiat. Hal ini merupakan sesuatu yang haram menurut ijma muslimin, sebagaimana yang dapat dilihat dalam hadis yang diriwayatkan oleh Ibnu Mâjah dari Abu Mâlik al-Asy'ari.

${ }^{46}$ Imam Al-Ghazâli Abu Hâmid (w. 505 H), Ihyâ' 'Ulum ad-Dîn, (Beirut: Dâr al-Kutub al'Ilmiyyah, 1986) jld. 2, h. 297; Ibnu Hajar al-Haitamy, al-Zawâjir 'an Iqtirâf al-Kabâir, (Dâr alMa'rifah: Beirut, 1998), jld. 2, h. 424. Dalam mazhab Syâfíi juga ditemukan perbedaan pendapat yang cukup panjang berkenaan dengan hukum nyanyian dan musik. Ibnu Hajar al-Haitamy yang bermazhab Syâfi'i membahas bab ini dalam al-Zawajijir dengan panjang lebar dan menyatakan bahwa mayoritas ulama Syafi'iyah mengatakan musik adalah haram termasuk Imam al-Syirâzî, alNawawî, dan al-Adzra'î. Diantara ulama yang memperbolehkan hal ini adalah Imam al-Ghazâli, al-Isnawi, al-Mâwardi, al-Khaththâbi, al-Ruyyâni, dan Muhammad bin Yahya. Syeikh M. al-Ghazâlî sendiri mendukung penuh pengharaman nyanyian dan menganggapnya ittifaq serta mencela keras golongan yang memperbolehkannya. Lihat Ibnu Hajar al-Haitamy, al-Zawâjir 'an Iqtirâf al-Kabâiir, h. 404-417.

${ }^{47}$ Ibnu Hazm al-Zhâhirî, al-Muhalla bi al-Atsar, (Beirut: Dâr al-Kutub al-'Ilmiyyah, 1998), jld. 9, h. 56. Dalam kitab Neil al-Authâr, Imam al-Syaukâny mengutip bahwa Ahmad bin Hanbal dan Yahya bin Ma'in telah mengkritik Shadaqah bin Khâlid. Beliau membahas bab ini dengan panjang lebar dan menjelaskan argumentasi kelompok yang memperbolehkan dan golongan yang mengharamkan nyanyian secara detail. Dari bahasan ini terlihat jelas pengharaman lagu dan musik bukanlah ijma' tetapi merupakan perkara khilafiyah di kalangan ulama. Lihat al-Syaukâny, Neil alAuthâr syarb Muntaqâ al-Akbbâr, (Damaskus: Dâr al-Khari, 1998), jld. 4, h. 433-443.

${ }^{48}$ Ibnu Mâjah Muhammad bin Yazîd al-Qazwainy (w. 273 H), Sunan Ibnu Mâjah, Kitâb al-Fitan, Bab al-'Uqubât, hadis no. 4020. Lihat juga komentar syeikh M. Yusuf al-Qaradhawi, Fatâwa al-Mu'ashirah, (Kairo: Dâr al-Wafa', 1994), jld. 2, h. 494. 
M. al-Ghazâlî juga mengemukakan alasan lain bahwa Rasulullah saw bersabda: "Akan ada dari kalangan umatku yang meminum arak mereka menamakannya dengan nama yang lain, bersamaan dengan nyanyian, musik, penyanyi-penyanyi wanita, lalu Allah menenggelamkan mereka dan ada yang dijadikan kera dan kbinzir" ${ }^{2}{ }^{4}$

Kesimpulan dari pembahasan mengenai hadis ini adalah sanad dan tunjukan hadis ini tidak bersifat shahîh dan tidak dapat menghasilkan hukum pengharaman terhadap nyanyian dan musik. Menurut ilmu Mustalah Hadis, hadis mu'allaq termasuk hadis daif dan tidak menjadi hujah dalam syariah. Akan tetapi umat Islam dianjurkan menggunakan kaedah ibtiyat (berhati-hati) dalam perkaraperkara syubuhat (samar-samar) seperti ini. Dengan demikian jelaslah sekalipun Syeikh M. al-Ghazâlî menggugat status hadis mengenai musik dan nyanyia, namun ia tidak menghalalkannya bahkan menganjurkan agar umat Islam meninggalkannya untuk menjauhkan diri dari perkara syubhat.

\section{Kesimpulan}

Dari paparan diatas dapatlah ditarik beberapa kesimpulan mengenai pemikiran Syeikh Muhammad Al-Ghazali dalam bukunya as-Sunnah al-Nabawiyyah baina Abl al-Fiqh wa Abl al-Hadìts sebagai berikut: Pertama, Kedudukan hadis aḥād sebagai sumber hukum apalagi akidah menjadi perdebatan di kalangan ulama hadis sejak masa lampau hingga saat ini. Oleh karena itu, adalah tugas para pecinta hadis Nabi saw untuk mencurahkan perhatian mereka untuk memilah dan memilih dari sekain banyak hadis aḥa d yang dapat dijadikan hujjah.

Kedua, Hadis ahad yang terdapat dalam periwayatan al-Bukhari dan Muslim diyakini para ulama hadis dan jumhur ulama sebagai hujjah yang kuat setelah al-Qur'ân. Keyakinan ini terus berlanjut hingga hari ini, para ulama sepakat bahwa seluruh hadis yang diriwayatkan oleh keduanya menjadi dalil dalam permasalahan hukum dan akidah. Adapun pemahaman terhadap makna hadis dengan pendekatan tekstual atau kontektual merupakan permasalahan selanjutnya dalam menganalisa konten makna dari suatu hadis. Dalam permasalahan ini, perdebatan di kalangan ulama tidak kalah sengitnya.

Ketiga, Pandangan Syeikh Muhammad Al-Ghazâlî tentang kedudukan hadis ahad tidaklah berarti ia menolak seluruh hadis ahad. Akan tetapi pendapat itu mengajak para peneliti hadis agar lebih teliti dan kritis dalam memahami konteks dan kontens dari suatu hadis, menyesuaikannya dengan rasionalitas pemikiran yang jernih dan sesuai dengan perkembangan kehidupan modern saat ini. Sebagai contoh misalkan dia tidak mempraktekkan hadis ahad tentang lalat, yang apabila lalat masuk ke air minum seseorang, lalu dia membuangnya saja

49 Imam Ahmad bin Hanbal, al-Musnad, Baqi Musnad al-Anshar, hadis no. 25842. Lihat juga 'Abd al-'Azhîm al-Munzhirî, al-Targhib wa al-Tarbib, (Beirut: Dâr al-Kutub al-Ilmiyyah, 2001), jld. 1, h. 131. 
dibandingkan memilih untuk mencelupkan kembali lalat tersebut dan meminumnya, hal ini tidak lah merusak keimanan dan akidah seseorang.

Penelitian terhadap sanad dan matan suatu hadis merupakan pekerjaan serius yang mesti dijalankan oleh para ahli hadis. Sebab, jika hal tersebut tidak dilakukan dan hanya merujuk kepada pemahaman terdahulu, maka apa kontribusi ahli hadis kontempror terhadap pengembangan kajian hadis. Tentunya tugas mulia ini bukan sekedar daur ulang dari pernyataan ulama hadis klasik akan tetapi turut serta terjun langsung dalam seluk beluk penelitian hadis itu sendiri. Dengan cara itu pula kajian hadis akan menjadi berkembang dan menarik tidak stagnan dan membosankan.

\section{Bibliografi}

Abu Daud al-Thayâlisî Sulaiman bin Daud bin al-Jârûd (w. 204 H), Musnad alThayâlisî. Riyadh, Dâr al-Hijrah, 1999.

al-'Audah, Salman bin Fahd. al-Hiwâr al-Hâdi' ma'a Mubammad al-Ghazâlî. Riyadh: Dâr a-Wathan, 1992.

al-'Azhîm, Ibnu al-Munzhir 'Abd. al-Targhib wa al-Tarbib, Beirut: Dâr al-Kutub alIlmiyyah: 2001.

Al-Albânî, Muhammad Nasir al-Dîn. Shifat Shalât al-Nabi. Riyadh: Maktabat alMa'ârif, 2002.

-. Silsilât al-Ahadits al-Sabîhah. Beirut: al-Maktab al-Islami, 1998.

al-Bustî, Ibnu Hibbân Muhammad bin Hibbân bin Ahmad bin Hibbân al-Tamîmy Abu Hâtim ad-Dârimî. (w. 354 H) Shahîh Ibnu Hibbân. Beirut: Muassasah ar-Risâlah: 1999.

Al-Ghazâli, Abu Hâmid. al-Mushtashfa min Tlm al-Ushûl. Beirut, Dâr Ihya' al-Turâts al-'Arabi: 1997.

-. Ibyâ' 'Ulûm ad-Dîn. Beirut: Dâr al-Kutub al-'Ilmiyyah, 1986.

al-Ghazali, Muhammad. Dustûr al-Wabdah al-Thaqafiyyah baina al-Muslimîn, Damaskus: Dâr al-Qalam, 1986.

--. al-Sunnah al-Nabawiyyah baina al-Figh wa Abl al-Hadits. Kairo: Dâr alSyurûq, 1996.

-. al-Tharîq min Hunâ. Kairo: Dâr al-Bashîr, 1987.

- Kaifa Nata 'âmal ma'a al-Qur'ân. Kairo: Dâr al-Wafâ', 1993.

-. Nazh harât fí al-Qur'ân. Kairo, Dâr al-Nahdhah, 1996.

- Qadzẩif al-Haqq. Beirut: Dâr al-Qalam, 1997.

--.-. Sirr Ta'akhkhur al-'Arab wa al-Muslimîn. Kairo: Dâr al-Nahdah, 1996.

-. Turâtsunâ al-Fikeri fì Mĩzân al-Syar' wa al-'Aql. USA: The International Institute of Islamic Thought: 1996.

al-Haitamy, Ibnu Hajar. al-Zawâjir 'an Iqtirâf al-Kabâ'ir. Beirut: Dâr al-Ma'rifah, 1998.

al-Harrâni, Ahmad bin Hanbal. al-Musnad. Beirut: Muassasah ar-Risâlah, 1999. 
754 | AL QUDS : Jurnal Studi Alquran dan Hadis vol. 5, no 2, 2021

Al-Juwayni, Abu al-Ma'aly Abd. Malik bin Yusuf. al-Burbân fì 'Usbâl al-Fiqh. Kairo: Dâr al-Wafa', 1992.

Al-Khathib, Muhammad 'Ajaj. Ushôl al-Hadìts 'Ulûmubu wa Musthalâbubu. Bairut: Dâr al-Fikr, 1989.

al-Mudhkali, Rabî’ bin Hâdi. Kasyf Mawâaif al-Ghazâầ min al-Sunnah wa Ablihâ. Madinah: Maktabah Ibn al-Qayyim, 1991.

al-Qardhawi, Muhammad Yusuf. al-Marji'iyyah al-'Ulyâ fí al-Islâm. Kairo: Maktabah Wahbah, 1998.

--- Fatâwa al-Mu'ashirah. Kairo: Dâr al-Wafa', 1994.

al-Shalâh, Ibnu. Muqaddimah Ibnu al-Salâh. Beirut: Muassasât al-Kutub alThaqafiyyah, 1997.

al-Zhâhirî, Ibnu Hazm. al-Ibkâm fî Ushûl al-Abkâm. Kairo: al-'Asimah, 1934.

al-Zhâhirî, Ibnu Hazm. al-Muballa bi al-Atsar. Beirut: Dâr al-Kutub al-'Ilmiyyah, 1998.

Asy-Syaukani, Neil al-Authâr syarb Muntaqa al-Akbbar. Damaskus: Dâr al-Khari, 1998.

Ath-Thabrâni, Sulaiman bin Ahmad bin Ayyub Abu al-Qasim. Musnad al-Syâmizîn. Beirut, Muasasah ar-Risâlah: 1984.

Basid, Abdul. "Kritik Terhadap Metode Muhammad Al-Ghazali Dalam Memahami Hadits Nabi Muhammad Saw", Jurnal Kabilah Vol. 2 No. 1 Juni 2017.

Fadhl, Ibnu Hajar al-'Asqalani Ahmad bin Ali bin Hajar Abu. (w. 852 H). Taghliq al-Ta'lì 'Ala Shabîh al-Bukbârî. Beirut: al-Maktab al-Islâmî, t.th.

Fadhl, Ibnu Hajar al-'Asqalani Ahmad bin Ali bin Hajar Abu. Fath al-Bârî syarh Shabîh al-Bukhârî, Beirut: Dâr al-Ma'rifah, 1379.

Fadhl, Ibnu Hajar al-'Asqalani Ahmad bin Ali bin Hajar Abu. Nu₹hat al-Nazdar fi taudhîh Nukbbah al-Fikar. Beirut: Dâr al-Arqam, 1996.

Idris, Mhd. "Metode Pemahaman Hadis Muhammad Al-Ghazali" Jurnal Ulunnuba Vol.6 No.1/Juni 2016.

Ismail, Syuhudi. Kaidah Kesahihan Sanad Hadis. Jakarta: Bulan Bintang, 1995.

Mahmud, Jami'. Ikhwanul Muslimin yang Saya Kenal. terj. Munirul Abidin. Jakarta: Pustaka al-Kautsar, 2005.

Muhammad Syams al-Haq al-'Azhîm Âbâdî Abu Thaiyyib, 'Aun al-Ma'bûd syarh Sunan Abi Daud, Beirut: Dâr al-Kutub al-'Ilmiyah: 1415 H.

Purwaningsih, Sri. "Kritik Terhadap Rekonstruksi Metode Pemahaman Hadis muhammad Al-Ghazali", Jurnal THEOLOGLA, Vol 28 No 1 (2017).

Suryadi. Metode Pemahaman Hadis Nabi (Telaah Atas Pemikiran Muhammad AlGhazâlî dan Yusuf al-Qardhawi, Yogyakarta: Program Pasca sarjana UIN Sunan Kalijaga, 2004.

Syahidin, Syahidin. "Kehujahan Hadis Ahad menurut Muhammad al-Ghazali, suatu kajian terhadap otoritas hadis ahad sebagai sumber ajaran Islam", Jurnal El-Afkar Vol. 6 Nomor 1, Januari-Juni 2017.

Syaltut, Mahmud. al-Islâm; 'Aqidah wa Syari'ah. Kairo: Dâr al-Shurûq, 1980. 